\title{
Cassia auriculata L.: An Ethno Medical Approach in Exploring Anti-solar Efficacy
}

\author{
Krantisinha Hanumant Randive ${ }^{1, \star}$, Ravindra Durdundayya Hiremath ${ }^{1}$, Amolkumar Ashok Kempwade $^{2}$, \\ Anagha Ashok Patil ${ }^{2}$
}

1'Department of Pharmaceutical Chemistry, KLES's College of Pharmacy, Nipani, Karnataka, INDIA.

'Department of Pharmaceutics, KLES's College of Pharmacy, Nipani, Karnataka, INDIA.

\begin{abstract}
Objectives: The present study deals with an in-vitro screening for the anti-solar potential of aqueous and ethanolic extracts of Cassia auriculata using the UV method. Methods: Aqueous and ethanolic extracts were prepared. Thus, prepared extracts were subjected to phytochemical investigation and evaluated for antioxidant effect using DPPH and antisolar efficacy. Concentrations ranging from 7.8 to $1000 \mu \mathrm{g} / \mathrm{mL}$ (serial dilution) were used for the determination of radical scavenging effect and concentration of $2 \mathrm{mg} / \mathrm{mL}$ was used for screening of anti-solar potential using Shimadzu UV-1700 double beam UV-Visible spectrophotometer. Readings were recorded in triplicate and graphs were extrapolated. Results: Extracts revealed the presence of important phytoconstituents such as phenols, triterpenoids, flavonoids, tannins, saponins, phytosterols, alkaloids and glycosides. Further, it was observed that Cassia auriculata possesses remarkable antioxidant activity. Significant results of the anti-solar screening study confirm its use as a natural sunscreen. It showed a protective effect against carcinogenic UV radiation. Ethanolic extract was found to be more effective in comparison with aqueous extract. Conclusion: From the data, it can be concluded that aqueous and ethanolic extracts showed promising antioxidant and anti-solar activity which could be considered as a rational alternative to chemically prepared synthetic sunscreen formulations available in the market.
\end{abstract}

Key words: Anti-solar, Carcinogenic, Cassia auriculata Linn, DPPH, SPF, UV.

\section{INTRODUCTION}

Skin: the largest organ comprising almost about $16 \%$ of body mass, formed by bilayers epidermis and dermis. The epidermis is the outermost layer gets exposed to environmental hazards. It plays a major role in the protection and management of the harmful effects of environmental factors such as chemicals, UV radiation and infectious pathogens. ${ }^{1}$ These solar UV radiations are classified as UVC (200-280 nm), UVB (280-320 nm) and UVA (320-400 $\mathrm{nm}){ }^{2}$ UVC being most harmful could not penetrate the ozone layer. UVB is found to be almost 30-40 times more potent compared to UVA and is mainly responsible for biological damage as well as anomalies in DNA. ${ }^{3}$ Skin is continuously exposed to UVB radiation. It suffers from various damaging effects, ranging from acute damages like erythema, pain, edema followed by chronic damages like premature aging, skin wrinkling, cataracts and cancer. Also, oxidation of protein and MMPs (metalloproteinases) was observed due to UVB. ${ }^{4}$ Skin protects itself from this radiation by producing melanin which darkens the skin due to pigmentation: a tendency of melanin. In this context, the use of topical formulations (with Sun Protection Factors-SPFs) to the skin may be a preferred choice to act as a sunscreen (Table 1). It may scatter, reflect or absorb the harmful radiation falling on the skin. These sunscreens are grouped as chemical and physical sunscreens. ${ }^{5}$ There is
Submission Date: 16-03-2019; Revision Date: 26-04-2019; Accepted Date: 20-07-2019

DOI: 10.5530/ijper.53.4s.164 Correspondence: Mr. Krantisinha Hanumant Randive,

Assistant Professor, Department of Pharmaceutical Chemistry, KLES's College of Pharmacy, Nipani-591237, Karnataka, INDIA. Phone: +919860193001 E-mail: krantisinharandive1@ gmail.com

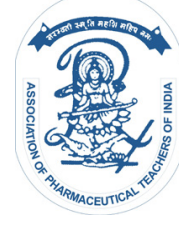

www.ijper.org 
a substantial growth in cosmetics and sunscreen market, which is an indication of consciousness among the peoples about hazardous effects of sunlight as well as about their looks, if not taken proper precautions. These sunscreens are associated with some side effects and contraindicated in patients using some other medications. Some adverse effects reported are contact dermatitis, burning, phototoxic, Vitamin D deficiency and estrogenicity, ${ }^{6}$ Damaging DNA, mutation, hormonal imbalance and allergic manifestations particularly in the patients allergic to benzocaine, procaine etc. ${ }^{7}$ This situation has alarmed to search for new safe and efficacious anti-solar agents from natural origin. Plants or herbs are used for their therapeutic potentials since ancient times. Polyphenols, Vitamin C, Vitamin E is reported to have a significant protective role in UV radiation-induced skin damage. ${ }^{8}$ Natural products are still practiced for their ability to treat and cure dermatological diseases and enhance skin appearance also. Earlier studies have already proved the anti-solar potential of many herbal products. Plants consist of many photolabile compounds that may get degraded as plants are continuously exposed to sunlight. Plants consisting of ascorbic acid, tocopherol, flavonoids and polyphenols exert antioxidant action and are observed to protect photosensitive components in plants. This results in inhibition of photo degradation of photo-labile compounds. ${ }^{9}$

Cassia auriculata L. (Family Ceasalpinaceae) is a commonly available plant in India. Traditional and reported literature about this plant confirms the presence of secondary metabolites such as phenolics, alkaloids, flavonoids, anthraquinone compounds, saponins, proteins, tannins, etc. which are thought to be responsible for efficacious therapeutic effect. ${ }^{10}$ In the present study effect of aqueous and ethanolic extract of Cassia auriculata L. is evaluated for its anti-solar potentials using a UV spectrophotometer.

\section{MATERIALS AND METHODS}

\section{Preparation of Extract}

The fresh flowers of Cassia auriculata L. were collected from surrounding areas of Gadhinglaj, District Kolhapur, Maharashtra, India. Authentication (Voucher Specimen No GSK-1) of the plant was done by the Department of Botany, Shivaji University, Kolhapur, Maharashtra, India. The flowers collected and authenticated were shade dried and powdered for extraction purposes. The powdered flowers were subjected to the cold maceration method using water and ethanol (95\%) as solvents. For extraction, $100 \mathrm{~g}$ dry powder and 500 $\mathrm{mL}$ each of water and ethanol was taken; macerated for two days with occasional shaking. Further, the macerates (aqueous and ethanolic) were filtered to remove any solid particles (if any) and dried. The dried extracts were used for phytochemical investigation and antisolar activity. ${ }^{11}$

\section{Preliminary Phytochemical Investigation}

Preliminary Phytochemical investigation of aqueous and ethanolic extracts was carried out for the determination of the presence of secondary metabolites such as flavonoids, alkaloids, saponins, triterpenoids, steroids, tannins, glycosides and phenolics. ${ }^{12-14}$ (Table 2)

\section{Screening for in-vitro antioxidant activity by DPPH method}

DPPH (1, 1-diphenyl-2-picrylhydryzyl) solution was prepared with $5 \mathrm{mg}$ DPPH and $2 \mathrm{~mL}$ methanol, stored at $4^{\circ} \mathrm{C}$ away from light. Dried aqueous and ethanolic extracts were dissolved in methanol $(1000 \mu \mathrm{g} / \mathrm{mL})$ and stock solutions were prepared. Further, these stock solutions were diluted serially (two-fold dilution) to achieve

Table 1: Suitable SPF for Different sensitive skins.

\begin{tabular}{|c|c|c|c|}
\hline $\begin{array}{c}\text { Suitable } \\
\text { SPF }\end{array}$ & $\begin{array}{c}\text { Skin } \\
\text { Type }\end{array}$ & UV Sensitivity & Effect of UV radiation \\
\hline $10 \leq$ & I & Very sensitive & $\begin{array}{c}\text { Burns easily, never } \\
\text { tans }\end{array}$ \\
\hline $10 \leq$ & II & Very sensitive & $\begin{array}{c}\text { Burns easily, minimum } \\
\text { tanning }\end{array}$ \\
\hline 6 to 10 & III & Sensitive & $\begin{array}{c}\text { Moderately burns, } \\
\text { uniform and gradual } \\
\text { tanning to light brown }\end{array}$ \\
\hline 4 & IV & Moderately & $\begin{array}{c}\text { Minimum burning, } \\
\text { tans to moderate brown }\end{array}$ \\
\hline $\begin{array}{c}\text { Not } \\
\text { specified }\end{array}$ & VI & Not sensitive & $\begin{array}{c}\text { Never burns, black } \\
\text { pigmentation }\end{array}$ \\
\hline
\end{tabular}

\section{Table 2: Results of preliminary phytochemical inves-} tigation.

\begin{tabular}{|c|c|c|c|}
\hline \multirow{2}{*}{$\begin{array}{l}\text { Sr. } \\
\text { No. }\end{array}$} & \multirow{2}{*}{$\begin{array}{l}\text { Chemical } \\
\text { component }\end{array}$} & \multicolumn{2}{|c|}{ Cassia auriculata L } \\
\hline & & $\begin{array}{c}\text { Aqueous } \\
\text { Extract }\end{array}$ & $\begin{array}{c}\text { Ethanolic } \\
\text { Extract }\end{array}$ \\
\hline 1 & Flavanoids & + & + \\
\hline 2 & Triterpenoids & + & + \\
\hline 3 & Phenols & + & + \\
\hline 4 & Tannins & + & + \\
\hline 5 & Saponins & + & + \\
\hline 6 & Phytosterols & + & + \\
\hline 7 & Alkaloids & + & + \\
\hline 8 & Glycosides & + & + \\
\hline
\end{tabular}


a solution of $7.8 \mu \mathrm{g} / \mathrm{mL}$ (lowest concentration) in a well plate ( 96 well micro titer plates). A row of the negative control (methanol only) and Vit-C and quercetin were used as the reference standard. To each well $5 \mu \mathrm{DPPH}$ was added and stored the reaction mixture for $30 \mathrm{~min}$ protected from light. Using an Elisa Reader absorbance at $517 \mathrm{~nm}$ was recorded in triplicate and percentage scavenging potential was determined using the following formula. ${ }^{15}$ (Figure 1)

$\mathrm{DPPH}$ radical scavenging effect $(\%)=\frac{\mathrm{OD}(\mathrm{DPPH})-0 \mathrm{D}(\mathrm{DPPH}+\text { Sample })}{0 \mathrm{D}(\mathrm{DPPH})} \times 100$

\section{Screening for in-vitro anti-solar activity}

The anti-solar activity was determined by Shimadzu UV-1700 double beam UV spectrophotometer having a $1 \mathrm{~cm}$ quartz cell. Sample $(1 \mathrm{~g})$ was taken in a $100 \mathrm{~mL}$ volumetric flask and made up the volume with water and ethanol (95\%) individually. Shaken well and kept for 5 mins. Further, a $5 \mathrm{~mL}$ solution from each flask was diluted with $25 \mathrm{~mL}$ of water and ethanol (95\%) respectively, to achieve a final solution of $2 \mathrm{mg} / \mathrm{mL}$ concentration. UV absorption spectra of both aqueous and ethanolic $(95 \%)$ extracts were recorded in a range between 290-320 $\mathrm{nm}$. Three readings were recorded and the mean was calculated. ${ }^{16}$ Normalized product function [Table $3\left(\mathrm{EE}_{(\lambda)} \mathrm{I}_{(\lambda)}(\text { Constant })\right]^{17}$ and mean of absorbance was used to calculate SPF values. (Table 4)

$$
S P F=C F \times \sum_{320}^{200} E_{E}(\lambda) \cdot I_{(\lambda)}-a b s(\lambda)
$$

Where,

$\mathrm{CF}-$ Correction factor $=10$

EE - Erythemal effect spectrum

I - Solar intensity spectrum

Abs - Absorbance of prepared extracts (Aqueous and ethanolic)

\section{RESULTS}

Preliminary Phytochemical investigation confirms the presence of various secondary metabolites such as flavanoids, triterpenoids, phenols, tannins, saponins, phytosterols, alkaloids and glycosides (Table 2). Further, both aqueous and ethanolic extracts were screened for their antioxidant potential by using the DPPH method where it exhibits promising free radical scavenging effect (Figure 1). Ethanolic extract showed a more radical scavenging effect as compared to aqueous extract. In the present study anti-solar activity of aqueous and ethanolic extracts of Cassia auriculata L. was determined using Shimadzu UV-1700 double beam UV-Visible spectrophotometer. A solution of $2 \mathrm{mg} / \mathrm{mL}$ concentration was prepared for measuring absorption. Three

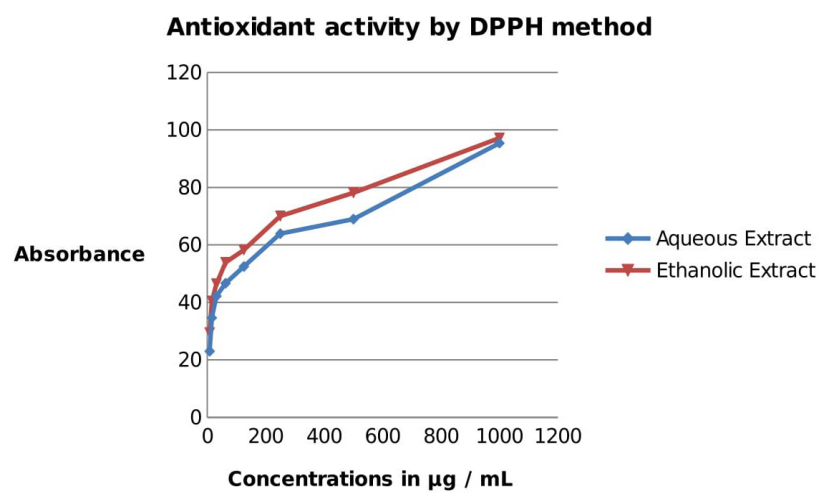

Figure 1: Antioxidant potential of aqueous and ethanolic extracts of Cassia auriculata L. using DPPH method.

Antisolar activity using UV-1700 Spectrophotometer

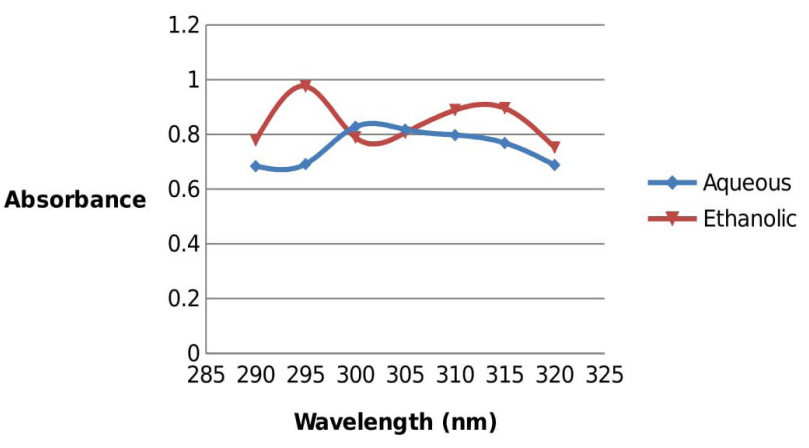

Figure 2: UV absorption of Cassia auriculata extracts.

\section{Table 3: Standard values of $E_{(\lambda)} I_{(\lambda)}$ used to calcu-} late Sun Protection Factor (SPF).

\begin{tabular}{|c|c|}
\hline Wavelength $(\mathbf{n m})$ & $\mathrm{EE}_{(\mathrm{\lambda})} \cdot \mathrm{I}_{(\lambda)}$ (Constant) \\
\hline 290 & 0.0150 \\
\hline 295 & 0.0817 \\
\hline 300 & 0.2874 \\
\hline 305 & 0.3278 \\
\hline 310 & 0.1864 \\
\hline 315 & 0.0837 \\
\hline 320 & 0.0180 \\
\hline Total & 1 \\
\hline
\end{tabular}

readings were recorded and presented the data in the form of a scattered diagram. From the results obtained, it can be stated that both aqueous and ethanolic extracts exert significant anti-solar activity. Ethanolic extracts showed absorption maxima $\left(\lambda_{\max }\right)$ at two different wavelengths i.e. $295 \mathrm{~nm}(0.976 \pm 0.003)$ and $315 \mathrm{~nm}(0.896$ $\pm 0.0035)$ whereas aqueous extract showed absorption maxima $\left(\lambda_{\max }\right)$ at $300 \mathrm{~nm}(0.828 \pm 0.0021)$ Using these $\lambda_{\max }$ values for both aqueous and ethanolic extracts, SPF value for aqueous and ethanolic extract was found to be 13.07 and 15.55 respectively (Table 4 and Figure 2). 


\begin{tabular}{|c|c|c|c|}
\hline \multirow{2}{*}{$\begin{array}{l}\text { Sr. } \\
\text { No. }\end{array}$} & \multirow[b]{2}{*}{$\lambda \mathrm{nm}$} & \multicolumn{2}{|c|}{ Absorbance $(n=3)$ Mean of three } \\
\hline & & $\begin{array}{l}\text { Aqueous } \\
\text { Extract }\end{array}$ & $\begin{array}{c}\text { Ethanolic } \\
\text { Extract }\end{array}$ \\
\hline 1 & 290 & $0.684 \pm 0.0025$ & $0.778 \pm 0.0035$ \\
\hline 2 & 295 & $0.692 \pm 0.0040$ & $0.976 \pm 0.003$ \\
\hline 3 & 300 & $0.828 \pm 0.0021$ & $0.789 \pm 0.0045$ \\
\hline 4 & 305 & $0.818 \pm 0.0025$ & $0.806 \pm 0.003$ \\
\hline 5 & 310 & $0.798 \pm 0.0025$ & $0.889 \pm 0.002$ \\
\hline 6 & 315 & $0.769 \pm 0.0031$ & $0.896 \pm 0.0035$ \\
\hline \multirow[t]{2}{*}{7} & 320 & $0.688 \pm 0.0035$ & $0.752 \pm 0.0026$ \\
\hline & SPF & 13.07 & 15.55 \\
\hline
\end{tabular}

\section{DISCUSSION}

White or fair skin complexion is highly susceptible to cutaneous melanoma due to the lesser quantum of dark pigments-eumelanin responsible for blocking UV radiation falling on the skin. Various harmful and undesirable effects on the skin such as inflammation, sunburns, tanning and peeling are observed due to exposure to UV radiation. ${ }^{1} \mathrm{UV}$ rays are also termed as "Complete Carcinogens" as in absence of any initiator and enhancer they can cause cancer. The effect is due to damage occurring to DNA, followed by the inability to regenerate. ${ }^{18}$ Human skin is frequently exposed to ultraviolet rays resulting in cell damage and inducing skin cancer. Melanin plays a vital role in skin pigmentation and serves as the most significant Solar Protection Factor. This activity is attributed to its UV absorbent and free radical scavenging effect. ${ }^{19}$ Also, proteins, lipids and nucleotides are natural UV radiation blockers of skin. Further, antioxidants are essential for the stimulation and regeneration of damaged skin. Antioxidant potential of aqueous and ethanolic extracts helps to speed up the recovery of damaged skin which contributes significantly to the anti-solar activity of the plant. Natural products are in medicinal practice since ancient days. They possess potential efficacy in treating many human ailments. Medicinal plants ability to treat skin infections or dermatological disorders and improvising the skin appearance is well established. ${ }^{6}$ Natural products are believed to be safe and economic with more acceptances among people. They act by different mechanism of actions such as detoxification of cancer causing factors, triggering immune response, gene suppression effect, protecting DNA from damage due to reactive oxygen species. ${ }^{4}$ Secondary metabolites from natural resources such as flavonoids, polyphenols, Vitamin E, Vitamin $\mathrm{C}$ are found responsible for anti-solar potential acting either by chemical or physical method. ${ }^{6}$ In the present study, aqueous and ethanolic extracts of Cassia auriculata L. were screened for its anti-solar potential. From the results obtained, it is revealed that both the extracts are absorbing UV radiation between the range $290-320 \mathrm{~nm}$, which are believed to be most harmful to the skin. This absorptive capacity may be attributed to the presence of flavonoids and polyphenols in both the extracts. It was evident from the previous studies that polyphenols exert remarkable antioxidant activity and also inhibit the damaging effect on DNA occurring due to harmful UV radiation. Also, it substantially nullifies various adverse biochemical events occurring due to solar UV radiation. ${ }^{20}$ Ethanolic extract comparatively showed a more promising result as compared to aqueous extract, because of more solubility of flavonoids and polyphenols in ethanol.

\section{CONCLUSION}

Both the aqueous and ethanolic extracts of dry flowers of Cassia auriculata L. can absorb UV radiation thought to be responsible for skin cancer, especially; ethanolic extracts. The synergistic effect of free radical scavenging potential and SPF values more than 10 assures significant protection from UV radiation. The proved anti-solar activity of the plant shows its importance and prophylactic utility in anti-solar formulations. This will be a safe, better and economic option to harmful chemical sunscreens that are used nowadays in the market.

\section{ACKNOWLEDGEMENT}

The authors are thankful to Principal, KLES's College of Pharmacy, Nipani-591237, India; for providing facilities to carry out this research work. The authors are grateful Department of Botany, Shivaji University, Kolhapur, Maharashtra, India for authenticating the plant material.

\section{CONFLICT OF INTEREST}

We wish to confirm that there are no known conflicts of interest associated with this publication and there has been no significant financial support for this work that could have influenced its outcome.

\section{ABBREVIATIONS}

UV: Ultraviolet; DPPH: 1, 1-diphenyl-2-picrylhydryzyl; FDA: Food and Drug Administration; EWG: Environmental working group. 


\section{REFERENCES}

1. D'Orazio J, Jarrett S, Amaro-Ortiz A, Scott T. UV radiation and the skin. International Journal of Molecular Sciences. 2013;14(6):12222-48.

2. Patil VV, Patil SB, Kondawar MS, Naikwade NS, Magdum CS. Study of methanolic extract of the flower of Spathodea campanulata L. as an antisolar. International Journal of Green Pharmacy. 2009;3(3):248-9.

3. Mbanga L, Mpiana PT, Mbala M, llinga L, Ngoy B, Mvingu K, et al. Comparative in vitro Sun Protection Factor (SPF) values of some herbal extracts found in Kinhasa by Ultraviolet Spectrophotometry. J of Physical and Chemical Sciences. 2015;2(4):1-6.

4. Pathak MA. Sunscreens: Topical and systemic approaches for protection of human skin against the harmful effects of solar radiation. Journal of the American Academy of Dermatology. 1982;7(3):285-312.

5. Afaq F, Zaid MA, Khan N, Dreher M, Mukhtar H. Protective effect of pomegranate-derived products on UVB-mediated damage in human reconstituted skin. Experimental Dermatology. 2009;18(6):553-61.

6. Donglikar MM, Deore SL. Development and Evaluation of Herbal Sunscreen. Pharmacognosy Journal. 2017;9(1):83-97.

7. Sambandan DR, Ratner D. Sunscreens: An overview and update. Journal of the American Academy of Dermatology. 2011;64(4):748-58.

8. Goswami PK, Samant M, Srivastava R. Natural sunscreen agents: A review. SAJP. 2013;2(6):458-63.

9. Korać RR, Khambholja KM. The potential of herbs in skin protection from ultraviolet radiation. Pharmacognosy Reviews. 2011;5(10):164.

10. Dichayal SS, Murade VD, Deshmukh KK, Hase DP, Hase G, Phatangare ND. Phytochemistry of Cassia auriculata (L.): A Review. World Journal of Pharmaceutical and Life Sciences. 2016;2(5):81-8.
11. Tabrizi H, Mortazavi SA, Kamalinejad M. An in vitro evaluation of various Rosa damascena flower extracts as a natural anti-solar agent. International Journal of Cosmetic Science. 2003;25(6):259-65.

12. Kokate CK. Practical Pharmacognosy-Techniques and Experiments. $9^{\text {th }}$ ed Pune: Nirali Prakashan. 2002;149-53.

13. Khandelwal KR. Practical Pharmacognosy-Techniques and Experiments $22^{\text {nd }}$ ed. Pune: Nirali Prakashan. 2012;23.1-5.

14. Harborne JB. Phytochemical Methods. $3^{\text {rd }}$ ed. London: Chapman and Hall.1998.

15. Muid S, Ali AM, Yusoff K, Nawawi H. Optimal antioxidant activity with moderate concentrations of Tocotrienol rich fraction (TRF) in in vitro assays. International Food Research Journal. 2013;20(2):687-94.

16. Golmohammadzadeh S, Jaafari MR, Hosseinzadeh H. Does saffron have anti-solar and moisturizing effects?. Iranian Journal of Pharmaceutical Research. 2010;9(2):133.

17. Sayre RM, Agin PP, LeVee GJ, Marlowe E. A comparison of in vivo and in vitro testing of sunscreening formulas. Photochemistry and Photobiology. 1979;29(3):559-66.

18. Matsumura $\mathrm{Y}$, Ananthaswamy $\mathrm{HN}$. Toxic effects of ultraviolet radiation on the skin. Toxicology and Applied Pharmacology. 2004;195(3):298-308.

19. Brenner M, Hearing VJ. The protective role of melanin against UV damage in human skin. Photochemistry and Photobiology. 2008;84(3):539-49.

20. Nichols JA, Katiyar SK. Skin photoprotection by natural polyphenols: Anti-inflammatory, antioxidant and DNA repair mechanisms. Archives of Dermatological Research. 2010;302(2):71-83.

\section{PICTORIAL ABSTRACT}

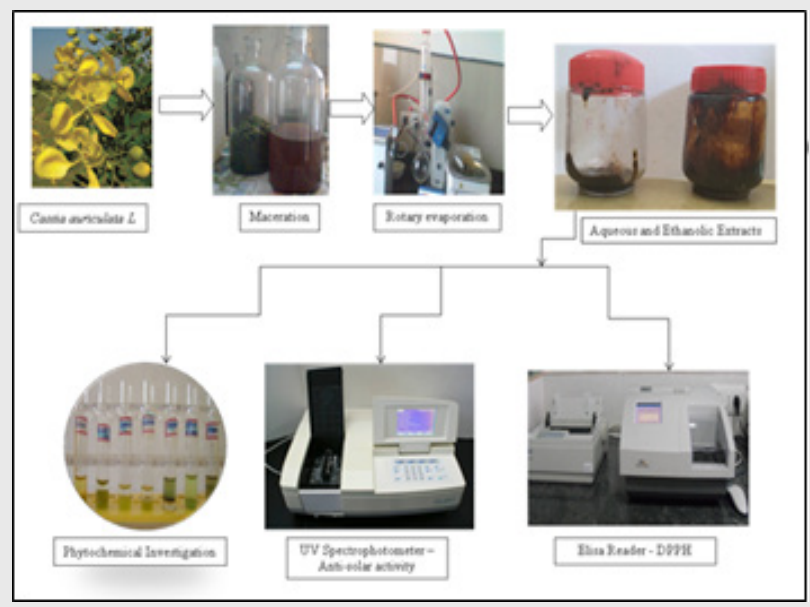

\section{About Authors}

\section{SUMMARY}

Current study; deals with the extraction and evaluation of aqueous and ethanolic extracts of flowers of Cassia auriculata $\mathrm{L}$ for their anti-solar and antioxidant potential by UV and DPPH method respectively. Phytochemical investigation of both extracts revealed the presence of flavonoids, triterpenoids, phenols, tannins, saponins, phytosterols, alkaloids and glycosides. Further, the anti-solar potential was evaluated by measuring the UV absorption capacity of both extracts. It was observed that aqueous and ethanolic extracts absorbed UV radiation to a significant level. Also, both the extracts showed promising free radical scavenging activity. Ethanolic extract showed a comparatively more potent antioxidant effect than aqueous extract. It can be summarized that significant UV absorptive properties with potent free radical scavenging effect are complementary to each other in exhibiting the promising anti-solar effect of Cassia auriculata $\mathrm{L}$

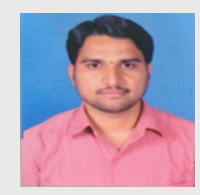

Krantisinha Hanumant Randive: Mr. Randive is working as Asst. Professor in the Department of Pharmaceutical Chemistry of KLE College of Pharmacy, Nipani. He is having 8 years of teaching Experience. He has published 3 research articles in National and International scientific journals of repute. His core area of research is synthesis of novel molecules, extraction of active constituents from herbal sources and screening for their therapeutic efficacy. 


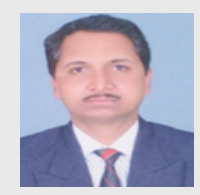

Ravindra Durdundayya Hiremath: Dr. Hiremath is working as Asso. Professor in the Department of Pharmaceutical Chemistry of KLE College of Pharmacy, Nipani. He is having more than 20 years of teaching and industrial experience. He has published 8 research articles in National and International scientific journals of repute and presented research papers in various conferences. His area of research is isolation, characterization of secondary metabolites from natural resources, synthesis of novel molecules and screening for their pharmacological action.

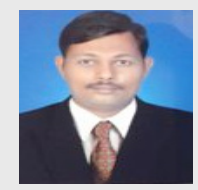

Amolkumar Ashok Kempwade: Dr. Kempwade is working as Asst. Professor in the Department of Pharmaceutics of KLE College of Pharmacy, Nipani. He is having more than 7 years of teaching and industrial experience. He has published 4 research articles in International scientific journals and having one patent to his credit. His core area of research is formulation and evaluation of various Novel Drug delivery Systems.

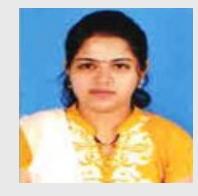

Anagha Ashok Patil: Ms. Patil is a Post Graduate Research Scholar in Department of Pharmaceutics, KLE College of Pharmacy, Nipani. She is presently working on submission of her research work. Also she has worked as lecturer for 1 year. Her area of specialization is formulation and evaluation of various Novel Drug delivery Systems and in-vitro bioequivalence studies of marketed formulations.

Cite this article: Randive KH, Hiremath RD, Kempwade AA, Patil AA. Cassia auriculata L.: An Ethno Medical Approach in Exploring Anti-solar Efficacy. Indian J of Pharmaceutical Education and Research. 2019;53(4s):s678-s683. 